\title{
How to Assess the MA Saudi Students in Journalistic Translation?
}

\author{
Adel Salem Bahameed \\ Associate Professor of Translation \\ Department of English \\ Faculty of Languages \& Translation \\ King Khalid University, Abha, Kingdom of Saudi Arabia
}

\begin{abstract}
Journalistic texts are important for translators to know how to handle because journalism, press, and media are essential fields where translators can work after graduation. This paper intends to illuminate the way for translation trainers concerning how the assessment process is supposed to be. It draws the attention to the usefulness of implementing Hurtado's approach of assessment on 18 male and female MA translation trainees at the Faculty of Languages and Translation at King Khalid University in KSA. This approach was applied to the correction of the final examination which includes diverse journalistic texts to be translated in both directions between Arabic and English. This is an empirical study and the findings are that linguistic competence of the translators was an essential factor and Hurtado's approach is found to be invalid for assessing the journalistic translations.
\end{abstract}

Keywords: assessment, Hurtado's approach, examination, translation mistakes, translation quality

\section{Introduction}

The question in the title is truly critical, as the answer is not available so far. This question leaves the translation teachers greatly mystifying especially after realizing that a solid benchmark to tackle this assessment issue is still non-existent. They understand that mistakes of journalistic translation do not all belong to one type. Stylistic mistakes could be regarded as rather less significant as committing structural and, probably, semantic mistakes. Big mistakes can cause a complete distortion to the message of the TL journalistic text when compared to relatively smaller mistakes. Therefore, they are not handled during the assessment process alike. In the academic environment, thus, we are still looking forward to finding a decent and effective scale (Hughes 2003). "The assessment paradox lies here in the fact that a single, reliable and objective assessment standard should be applied to an a priori subjective activity". (Kavytska \& Kvasova 2018: 200) (See also Hatim, 2001; Hurtado \& Martinez 2001). Meanwhile, a thorough look gives an obvious fact that the current related literature concerning the assessment matters of translation is still theoretically oriented for the most part.

On the other hand, a close probe at previous studies regarding the matter at hand shows that most of them are not empirically oriented. They, for all intents and related purposes, concentrate theoretically on matters like (1) Comparing translation mistakes with language mistakes (Kussmaul 1995); (2) Establishing the criteria for a "good translation" (Newpoint 1991); (3) Assessment according to the psycholinguistic "scenes and frames" theory (Bensoussan \& Rosenhouse, 1994; Snell-Hornby, 1995); (4) The need to assess quality at a pragmatic scale as an extra dimension (Hatim \& Mason, 1997; Hewson, 1995; Kussmaul, 1995; Sager, 1989; Williams, 1989); (5) Creating a pertaining system of translation mistakes (Kussmaul, 1995; Pym, 1992; Williams 1989); among others.

Additionally, empirical researches on assessment issues of students' translations are not hitherto numerous. Such researches comprise: (1) Campbell (1991) undertakes a study that has been carried out on 38 respondents of four dissimilar groups with the objectives of examining translation tests to see to what extent they examine the translation capability as well as disclosing translation processes rather than translation as a product. The languages involved in the study are English and Arabic. The researcher used the correlation matrix of ten analyses for the 38 respondents that included ten criteria such as lexical variety ratio, average word length, words omitted, among others. He inferred the existence of three separate factors. They are lexical transfer competence, global target language competence, and lexical coding of meaning. (See also Stansfield et al. 1992; Séguinot 1989 \& 1990).

2) Waddington (2004) wrote his research about evaluating the translators' work, which contributed a lot to complete writing his Ph.D. thesis. His research has been attracting a great deal of attention since then as he aimed at contriving a proper approach to carry out a proper assessment of translation at European universities. In his research, he simple compared between two previously used approaches of the mistake analysis and a holistic one. His research contributed to enriching and revisiting research in the area of assessment and enlightened the translation teachers more in this regard. 
3) Bahameed (2019) has recently published an empirical investigation using a holistic assessment technique with an aim to provide a type of guidance to translation teachers concerning how the assessment process is supposed to be. The study has the significance of trying to find the most applicable evaluative technique for students' conversions. This approach was applied to the correction process of a fifty-page project as a main requirement of the MA translation program. English and Arabic languages are involved in this investigation which was empirically done in Saudi Arabia. Only five female MA students constitute the study sample and this technique was considered too lenient to rely on as shown in the main study results.

4) Kavytska and Kvasova (2018) have offered their experimental research to shed light on evaluating translating exams as an essential part of translation teaching. The focus was mainly on the process rather than the product of translation. The research respondents were 33 students pursuing their MA degree in translation and five translation teachers. The main goal of this study was to reconsider the previous approaches of assessment in an attempt to create an innovative technique for evaluating the textual competence of translation in a Ukrainian atmosphere. The findings are that the innovative technique was significantly well-organized for appraising the textual competence of translation.

Having carefully considered the views of the works mentioned above, the present paper differs in the following aspects:

1. I applied only one specific Hurtado's approach excluding the mistake analysis approach and the holistic approach to see to what extent the former approach is sensibly appropriate.

2. Applying this approach to the correction process of translations was done under the final exam atmosphere.

3. I formulated the final exam of the course of Economic and Media Translation for the MA students. This exam considers the level of the respondents as I have been teaching translation courses for more than 12 years so far.

4. This paper considers the results acquired from this research in an attempt to enhance the quality of the translation MA program to the coming students of the university.

5. The current study emphasizes the need to investigate journalistic translation. This indicates that the final exam would contain a considerable number of journalistic terminology. That would constitute a favorable chance to see how the sample elements would handle this type of text.

\section{Experiment Description}

\subsection{Hurtado's Approach of Assessment}

Scholars of translation assessment have made creative endeavors to survey the translators' product including Kussmaul's (1995:129) error analysis approach, Waddington's (2001 and 2004) holistic approach, and Kavytska and Kvasova's (2018) technique for assessing the textual competence of translators, among others. A portion of these approaches is supposed to be progressively reasonable for translation beginners. I embraced Hurtado's (1995) approach as it seems, from all accounts, more compatible with the sample level of this examination. Hurtado's approach depends on error analysis as well. However, it varies in some calculations. The mistakes that are likely to occur are gathered under the headings shown in Table 1 below:

Table 1: A Scale of Hurtado's Assessment Approach

\begin{tabular}{|c|c|c|}
\hline Heading 1 & Heading 2 & Heading 3 \\
\hline $\begin{array}{l}\text { Wrong renderings which influence the } \\
\text { comprehension of the source text } \\
\text { including the following linguistic } \\
\text { genres: }\end{array}$ & $\begin{array}{l}\text { Wrong renderings which } \\
\text { influence } \\
\text { comprehension in the } \\
\text { target text including } \\
\text { following linguistic genres: }\end{array}$ & $\begin{array}{l}\text { Inadequate renderings } \\
\text { which influence the } \\
\text { transmission of either: }\end{array}$ \\
\hline $\begin{array}{l}\text { contresens (i.e. mistranslation) } \\
\text { faux sens (i.e. wrong meaning) } \\
\text { nonsens (i.e. nonsensical) } \\
\text { addition } \\
\text { omission } \\
\text { unresolved extralinguistic references } \\
\text { loss of meaning } \\
\text { improper linguistic variation (register, } \\
\text { style, dialect, and so on.). }\end{array}$ & $\begin{array}{l}\text { spelling } \\
\text { grammar } \\
\text { lexical items } \\
\text { text } \\
\text { style }\end{array}$ & $\begin{array}{l}\text { The main function of the } \\
\text { source text. } \\
\text { Subordinate function of } \\
\text { the source text. }\end{array}$ \\
\hline
\end{tabular}


In each of the genres, a slight differentiation is made between major mistakes ( -2 points) and minor mistakes $(-1$ point) that is contingent on the corrector who needs to pass judgment on the extent of the negative impact that every one of these mistakes has caused on the TL version. All this ought to be applied to the journalistic texts that should be rendered using different translation directions (from English into Arabic and the other way around).

In addition, there is a fourth genre that portrays the plus points to be granted for good ( +1 point) or exceptionally good solutions ( +2 points) for those respondents who impeccably figured out how to deal with the translation problems. To comprehend Hurtado's revision approach, consider Table 2 below:

Table 2: A Scale of Hurtado's Assessment Approach

\begin{tabular}{|l|l|l|}
\hline $\begin{array}{l}\text { (1) Inappropriate renderings which affect the } \\
\text { understanding of the source text }\end{array}$ & Minor Mistake & Serious Mistake \\
\hline Mistranslation & -1 point & -2 points \\
\hline Wrong meaning & -1 point & -2 points \\
\hline Nonsensical & -1 point & -2 points \\
\hline Addition & -1 point & -2 points \\
\hline Omission & -1 point & -2 points \\
\hline Unresolved extralinguistic references & -1 point & -2 points \\
\hline Loss of meaning & -1 point & -2 points \\
\hline $\begin{array}{l}\text { inappropriate } \\
\text { linguistic } \\
\text { variation }\end{array}$ Register & -1 points & -2 points \\
\hline $\begin{array}{l}\text { (2) Inappropriate renderings which affect expression } \\
\text { in the target language }\end{array}$ & -1 points & -2 points \\
\hline Spelling & -1 points & -2 points \\
\hline Grammar & -1 point & Serious Mistake \\
\hline lexical items & -1 point & -2 points \\
\hline Text and Style andect & -1 point & -2 points \\
\hline $\begin{array}{l}\text { (3) Inadequate renderings which affect the } \\
\text { transmission of the following }\end{array}$ & -1 point & -2 points \\
\hline The main function of the source text & -2 points \\
\hline Secondary functions of the source text & -1 point & Serious Mistake \\
\hline \begin{tabular}{l} 
(4) The plus points \\
\hline
\end{tabular} & $\begin{array}{l}\text { Good } \\
\text { Solutions }\end{array}$ & -2 points \\
\hline & +1 point & -2 points \\
\hline
\end{tabular}

On the account of the translation examination where this approach was utilized, the calculation of the negative points was deducted from 100 . The student needs 70 points to reach the lowest passing point (which is the normal Saudi system of assessment).

\section{The Hypothesis}

The hypothesis was that "the reasonableness and viability of utilizing Hurtado's approach of assessment are high and that it is conceivable to improve the nature of assessing the students' translations in future based on this approach." To verify this hypothesis, the outcomes acquired by applying this approach should be reasonable in the sense that students' failure cases should be within the range of 5\%-35\% out of the total number of the students.

\section{The Study Sample}

This study is set to portray issues related to translation assessment. This investigation concentrated on translation students purposefully. Non-random sampling was the method to select the study subjects. The students have been discriminated by the factor of gender and they have to be 18 Saudi MA males (2 students) and females (16 students) with almost the same age. They all belong to King Khalid University (KKU) in Saudi Arabia. The choice of these subjects is justified, as they constitute the highest potential sample available in such an academic institution. Besides. They are supposed to have a moderately decent command of English general language skills as well as their Arabic mother tongue. They have already taken many translation courses in their BA program and the first year of the MA program. Thus, they are supposed to have picked up the fundamental theoretical and practical abilities, which could greatly assist them with instant access to the written journalistic data of the source text with confidence.

\section{Final Examination}

The final examination consists of written texts taken from the field of journalism to be translated in both translation directions (See appendix). The test covers two purely journalistic passages. 
The first one speaks about the loss of some Latin counties due to cutting or burning the trees in the area. The topic is entitled 'Brazil Can't Stop Deforestation Without Aid'. This passage needs to be deciphered and translated into Arabic. It has 100 words shown in two paragraphs (See appendix). The second topic speaks about the last hurricane that happened in the Arab sea and the damages it caused in Oman and the areas nearby.

The topic is entitled 'آخر أخبار الإعصار الأخير في بحر العرب' (Latest news of the last hurricane in the Arabian Sea) and has only one paragraph. This topic has 83 words that should be rendered into English. Since the number of the first passage was a bit larger, it was given 60 marks out of 100 while the remaining 40 marks go to the second passage.

These two passages have been particularly selected from the local and international newspapers because they are remarkably loaded with journalistic terms that students are supposed to have grasped during their study of this course. Only paper dictionaries are allowed and students have 90 minutes to complete and check their translations. Generally, this final examination was rather similar to the ones adopted for the same course the last years and the correction process is pedantically executed out of 100 grades.

\subsection{The Application of the Scale}

Without a doubt, the hypothesis needs to be refuted or supported with a high degree of precision. In this manner, applying the grading procedure was made as orderly as possible. A red line is written down under the minor mistake and two lines are put under the genuine blunder according to Hurtado's Assessment Approach (See Table 2). At long last, all the lines are assembled and subtracted from the total of the student's general grades. To remove any possibility of bias, the students' grading procedure follows the flat strategy. It means that the evaluator was so careful to finish grading the primary question of all the responses. He then starts grading the responses related to the subsequent question. It should be noted that this approach was used by the researcher who is a specialist in (Arabic-English) translation according to his postgraduate qualification as well as to his long experience (over 11 years) in teaching courses of translation at the university level. That is the manner in which the current approach was utilized to do the information assortment and data collection. The next sections are going to show how the gathered data was analyzed and how the study results were inferred.

\section{Results}

Subsequent to analyzing the gathered data in the light of Hurtado's (1995) approach of assessment, Table 2 below shows the final results.

Table 3: The General Detailed Result

\begin{tabular}{|c|c|c|c|c|c|}
\hline Student No. & $\begin{array}{l}\text { Points out of } \\
100\end{array}$ & Result & Student No. & $\begin{array}{l}\text { Points out of } \\
100\end{array}$ & Result \\
\hline $\begin{array}{ll}\begin{array}{l}\text { Student } \\
\text { (female) }\end{array} & 1 \\
\end{array}$ & 86 & Pass & $\begin{array}{ll}\begin{array}{l}\text { Student } \\
\text { (female) }\end{array} & 10 \\
\end{array}$ & 86 & Pass \\
\hline $\begin{array}{ll}\begin{array}{l}\text { Student } \\
\text { (female) }\end{array} & 2\end{array}$ & 80 & Pass & $\begin{array}{ll}\begin{array}{l}\text { Student } \\
\text { (female) }\end{array} & 11 \\
\end{array}$ & 80 & Pass \\
\hline $\begin{array}{ll}\begin{array}{l}\text { Student } \\
\text { (female) }\end{array} & 3 \\
\end{array}$ & 72 & Pass & $\begin{array}{ll}\begin{array}{l}\text { Student } \\
\text { (female) }\end{array} & 12 \\
\end{array}$ & 94 & Pass \\
\hline $\begin{array}{ll}\begin{array}{l}\text { Student } \\
\text { (female) }\end{array} & 4\end{array}$ & 90 & Pass & $\begin{array}{ll}\begin{array}{l}\text { Student } \\
\text { (female) }\end{array} & 13 \\
\end{array}$ & 82 & Pass \\
\hline $\begin{array}{ll}\begin{array}{l}\text { Student } \\
\text { (female) }\end{array} & 5\end{array}$ & 70 & Pass & $\begin{array}{ll}\begin{array}{l}\text { Student } \\
\text { (female) }\end{array} & 14\end{array}$ & 76 & Pass \\
\hline $\begin{array}{ll}\begin{array}{l}\text { Student } \\
\text { (female) }\end{array} & 6\end{array}$ & 90 & Pass & $\begin{array}{ll}\begin{array}{l}\text { Student } \\
\text { (female) }\end{array} & 15 \\
\end{array}$ & 76 & Pass \\
\hline $\begin{array}{ll}\begin{array}{l}\text { Student } \\
\text { (female) }\end{array} & 7\end{array}$ & 92 & Pass & $\begin{array}{ll}\begin{array}{l}\text { Student } \\
\text { (female) }\end{array} & 16\end{array}$ & 82 & Pass \\
\hline $\begin{array}{ll}\begin{array}{l}\text { Student } \\
\text { (female) }\end{array} & 8 \\
\end{array}$ & 90 & Pass & $\begin{array}{ll}\begin{array}{l}\text { Student } \\
\text { (male) }\end{array} & 17 \\
\end{array}$ & 88 & Pass \\
\hline $\begin{array}{ll}\begin{array}{l}\text { Student } \\
\text { (female) }\end{array} & 9 \\
\end{array}$ & 92 & Pass & $\begin{array}{ll}\begin{array}{l}\text { Student } \\
\text { (male) }\end{array} & 18 \\
\end{array}$ & 94 & Pass \\
\hline
\end{tabular}

Table 2 gives the first inspiration that utilizing this approach has created no failure cases. Bearing in mind every student needs to get $70 \%$ of the total grades to successfully pass the examination. Less than that will cause failure according to the grading system at Saudi Universities. To be more specific, Table 3 below clarifies the results with percentages. 
Table 4: The Overall Collective Outcome

\begin{tabular}{|l|l|l|l|}
\hline Type & Pass & Fail & Total \\
\hline Frequency & 18 & 0 & 18 \\
\hline Percentage & $100 \%$ & $0 \%$ & $100 \%$ \\
\hline
\end{tabular}

The university assessment framework views this achievement rate as excessively high. In many modules, achievement doesn't typically surpass $90 \%$. To continue analyzing the data, the direction of translation was tallied up likewise to see whether this relevant factor has any impact. Table 4 beneath shows the overall result of Q1 that contained a journalistic text to be converted into Arabic and Q 2 that contained another journalistic text to be converted into English.

Table 5: The Impact of the Translation Direction on Failure Cases

\begin{tabular}{|c|c|c|c|c|c|}
\hline Student No. & $\begin{array}{l}\text { Direction } \\
\text { to Arabic } \\
\text { (60 points) }\end{array}$ & $\begin{array}{l}\text { Direction } \\
\text { to English } \\
\text { (40 points) }\end{array}$ & Student No. & $\begin{array}{l}\text { Direction } \\
\text { to Arabic } \\
\text { (60 points) }\end{array}$ & $\begin{array}{l}\text { Direction } \\
\text { to English } \\
\text { (40 points) }\end{array}$ \\
\hline $\begin{array}{l}\text { Student } \\
\text { (female) }\end{array}$ & 56 & 30 & $\begin{array}{ll}\begin{array}{l}\text { Student } \\
\text { (female) }\end{array} & 10\end{array}$ & 60 & 26 \\
\hline $\begin{array}{l}\text { Student } \\
\text { (female) }\end{array}$ & 50 & 30 & $\begin{array}{ll}\begin{array}{l}\text { Student } \\
\text { (female) }\end{array} & 11 \\
\end{array}$ & 46 & 34 \\
\hline $\begin{array}{l}\text { Student } \\
\text { (female) }\end{array}$ & 46 & 26 & $\begin{array}{ll}\begin{array}{l}\text { Student } \\
\text { (female) }\end{array} & 12 \\
\end{array}$ & 60 & 34 \\
\hline $\begin{array}{l}\text { Student } \\
\text { (female) }\end{array}$ & 58 & 32 & $\begin{array}{ll}\begin{array}{l}\text { Student } \\
\text { (female) }\end{array} & 13 \\
\end{array}$ & 52 & 30 \\
\hline $\begin{array}{l}\text { Student } \\
\text { (female) }\end{array}$ & 44 & 26 & $\begin{array}{ll}\begin{array}{l}\text { Student } \\
\text { (female) }\end{array} & 14 \\
\end{array}$ & 54 & 22 \\
\hline $\begin{array}{l}\text { Student } \\
\text { (female) }\end{array}$ & 58 & 32 & $\begin{array}{ll}\begin{array}{l}\text { Student } \\
\text { (female) }\end{array} & 15\end{array}$ & 46 & 30 \\
\hline $\begin{array}{l}\begin{array}{l}\text { Student } \\
\text { (female) }\end{array}\end{array}$ & 56 & 36 & $\begin{array}{ll}\begin{array}{l}\text { Student } \\
\text { (female) }\end{array} & 16 \\
\end{array}$ & 56 & 26 \\
\hline $\begin{array}{l}\text { Student } \\
\text { (female) }\end{array}$ & 52 & 38 & $\begin{array}{ll}\begin{array}{l}\text { Student } \\
\text { (male) }\end{array} & 17 \\
\end{array}$ & 54 & 34 \\
\hline $\begin{array}{ll}\begin{array}{l}\text { Student } \\
\text { (female) }\end{array} & 9\end{array}$ & 58 & 34 & $\begin{array}{ll}\begin{array}{l}\text { Student } \\
\text { (male) }\end{array} & 18 \\
\end{array}$ & 56 & 38 \\
\hline
\end{tabular}

The table above gives an indication that the factor of translation direction has no significant impact on the students' failure rate. Nobody failed and this is the first time this could happen. Nobody got less than half of the grades allotted for either question. In fact, there is a general belief among students and teachers that translation with the direction into one's mother tongue is always easier when compared to the other way around. However, the resulted cause no failure cases in both directions. This is a clear indication that this correction approach might be too lenient and allows all to become among the successful group with relative ease. This could also be justified that MA students are all brainy and have high linguistic competence in translation and writing skills.

\section{Discussions}

Pundits may state that Hurtado's approach of assessment is sensible. However, it needs more accuracy and objectivity in view of its partly reliance on the corrector's personal interference and understanding. For instance, the corrector can take away 1 or 2 points in accordance with his own capacity and personal decision. There is no definite gauge to choose either one as precisely as it is done in the other error analysis approach (Cf. Kussmaul 1995:129) in which the assessment process can lead to unbiasedly calculated points without the corrector's intervention. However, Hurtado's approach advocates defend it by saying that it is intelligently fine because the corrector would be, for the most part, a dependable expert who can decently take the correct choice with this respect. Moreover, all students were assessed fairly and blindly without distinction since the answer sheets of the final examination are given to the corrector after concealing the names of the students. This strategy is followed for all courses by a control board of the college.

On the other hand, investigating the students' collective outcome (Table 4) has given an overall impression that this approach is excessively lenient. It needs a specific amount of strictness and a kind of severity. This can be shown in the nonexistence of the failure cases when contrasted with the other error analysis approach that is accused of "devouring the students' points" and brought about the failure rate to reach one third out of the total. This signifies that Hurtado's approach is progressively tolerant towards the students as if students can easily pass the examination without much exertion and this necessitates reconsidering the assessment process. 
This presumably occurred because Hurtado's approach pushes the corrector to be tolerant and it limits him/her to deduct 2 points maximum for any kind of mistake despite the fact that some lexical, linguistic, or spelling mistakes were excessively genuine and merit more points to be deducted because such mistakes can cause serious deformation of the TL version. This approach is, therefore, unfair and rather ridiculous simply because one should bear in mind that the students were given sufficient time to check the spelling and meaning in the dictionary.

Thus, this supports the idea that the Hurtado's correction approach was not firm to the required degree and this resulted in other students who might not be studious enough to breeze through the examination and get success without having the competence required.

Then again, this approach regards lexical errors as inconsequential as well. In the other error analysis approach, the penalty of deducting 4 points occurs for the incorrect lexical item which means that a student chose an erroneous word or selected an improper meaning out of many meanings of a polysemous word. The penalty of the last approach was sensible in the light of the fact that making such a serious mistake could influence the overall sense of the sentence and most likely the other adjacent sentences. Other lexical mistakes include the omission mistake which happens when the student skips rendering a certain word. At the same time, loss of meaning could occur when the corrector feels that the meaning of a translated sentence is still obscure or blurred. The latter two cases could also cause harm to the meaning of the whole SL text. In Hurtado's approach, these mistakes are viewed as serious ones. However, they are penalized with -2 only.

Besides, it is noticed that the direction of translation was not a significant factor and that it doesn't have any vital link with the level of difficulty of the translation questions. Actually, it is commonly believed that most mistakes are committed in the question in which students are asked to translate a text from one's mother tongue into English. In our case, however, this assumption hasn't been supported as Hurtado's approach is too lenient to allow such a factor to stick out.

\section{Conclusions}

Even though Hurtado's approach was evenhandedly applied to all students without distinction, the result of having no failure case has made the defense in favour of this approach become too hard and that its high degree of lenience was remarkably undeniable.

One more disadvantage of this approach is that it cannot easily recognize the studious top respondents since the number of those who passed the exam are too many and that the failure cases are nonexistent. This gives an unfavorable impression that this approach is too lenient to the extent that it can give almost no opportunity to see the individual differences among the levels of the students. The lenience of this approach is also manifested, according to the results, in the fact that those students are not much accountable for the structural, semantic or spelling mistakes. Despite the fact that the correction process was carried out by a professional translation teacher, using Hurtado's approach still has a heavy reliance on the corrector's subjective intuition which might be too flexible and hard to measure.

As a matter of fact, it is generally felt that the subtraction of marks is smaller than the mistake committed. It ought to be borne in mind that when the penalty is small, the students would not try to correct themselves. They may inconsiderately continue submitting similar errors in the future. If the assessment scale is rather tough, this would surely urge the students to understand their mistakes and learn from them. They would become keen to correct themselves and avoid doing such mistakes after this. Therefore, there is a kind of concern and discomfort that students would not make much progress in translation if they were given easy passing in examination like that. In addition, the result has shown that carrying out this correction approach resulted in failure cases to be equal to zero. This would make us say that the study hypothesis regarding the suitability of utilizing this assessment analysis approach hasn't been verified.

Indeed, being too merciful like this will be contrarily reflected in the long run on the assessment quality framework and the teaching process in general. If the situation continued using the same policy, the alumni would be of low standard. Consequently, this is not appropriate for the university scholarly status and its position among the top academic institutions and the world universities ranking.

Finally, it is also concluded that the exam questions were sensible and rather easy. This has been proved by the result in which $100 \%$ of the students have scored the passing point. Therefore a recommendation is, therefore, worth mentioning here. It is that the examination must be longer and harder and the Hurtado assessment approach is invalid for correcting the translation students' works. Translation teachers must avoid using this approach and substitute it with another more reliable one.

\section{References}

Bahameed, A.S. (2019). Saudi MA Translators: An Assessment Issue. Arab World English Journal, Special Issue: The Dynamics of EFL in Saudi Arabia,. 22- 31 
DOI: https://dx.doi.org/10.24093/awej/efl1.2

Beaugrande, R. de. 1978. Factors in a Theory of Peotic Translating. Assen: van Gorcum; Amsterdam: Rodopi.

Bensoussan, M. and J. Rosenhouse. 1994. "Evaluating student translations by discourse analysis," Babel, 36-2, pp. 65-84.

Campbell, S. J. 1991. “Towards a Model of Translation Competence,” Meta 36-2/3, pp. 329-243.

Hatim, B. 2001. Teaching and Researching Translation. Pearson Education Limited, Edinburgh: Harlow, EssexCM20 2JE, England.

— and I. Mason. 1997. The Translator as Communicator, London, Routledge.

Hewson, L. 1995. "Detecting Cultural Shifts: Some Notes on Translation Assessment," Cross-Words. Issues and Debates in Literary and Non-literary Translating (I. Mason and C. Pagnoulle, eds.), Liège, L3, Liège Language and Literature, pp. 101-108.

House, J. 1981. A Model for Translation Quality Assessment, Tübingen, Gunter Narr.

Hughes, A. (2003). Testing for language teachers. Cambridge: Cambridge University Press.

Hurtado Albir, A. (1995). "La didáctica de la traducción. Evolución y estado actual," X Perspectivas de la Traducción, (P. Fernández, ed.), Valladolid, Universidad de Valladolid, pp. 49-74.

— and Martinez, N. (2001). Assessment in translation studies: Research needs. Meta: Translator's Journal, 46(2), 272-287.

Kavytska T., Kvasova O. (2018) Assessing Textual Competence in Translation into a Second Language. In: Hidri S. (eds) Revisiting the Assessment of Second Language Abilities: From Theory to Practice. Second Language Learning and Teaching. Springer, Cham.

Kussmaul, P. 1995. Training the Translator, Amsterdam, John Benjamins.

Newpoint, P. 1991. About Translation, Clevedon, Multilingual Matters.

Pym, A. 1992. "Translation Mistake Analysis and the Interface with Language Teaching," Teaching Translation and Interpreting. Training, Talent and Experience. Papers from the First Language International Conference, Elsinore, Denpoint, 31 May-2 June, 1991 (C. Dollerup and A. Loddegaard, eds.), Amsterdam, John Benjamins, pp. 279-288.

Sager, J. C. 1989. "Quality and Standards: The Assessment of Translations," The Translator's Handbook (C. Picken, ed.), London, ASLIB, pp. 91-102 [This is the second edition of The Translator's Handbook (1983)].

Séguinot, C. 1989. “Understanding Why Translators Make Mistakes,” TTR, 2-2, pp. 73-102.

— 1990. "Interpreting Mistakes in Translation," Meta, 25-1, pp. 68-73.

Snell-Hornby, M. 1995. "On Models and Structures and Target Text Cultures: Approachs of Assessing Literary Translations," La Traducció Literària (Josep Marco Borillo, ed.), Castelló de la Plana, Publicacions de la Universitat Jaume I, coll. "Estudis sobre la traducció," no 2, pp. 43-58.

Stansfield, C. W., M. L. Scott and D. M. Kenyon. 1992. "The Measurement of Translation Ability." The Modern Language Journal, 76-iv, pp. 455-67.

Williams, M. 1989. "The Assessment of Professional Translation Quality: Creating Credibility out of Chaos," TTR, 2-2, pp. 13-33.

Waddington, C. (2001). Different approachs of evaluating student translations: The question of validity. Meta: Translators' Journal, 46(2), 331-325.

\section{Appendix}
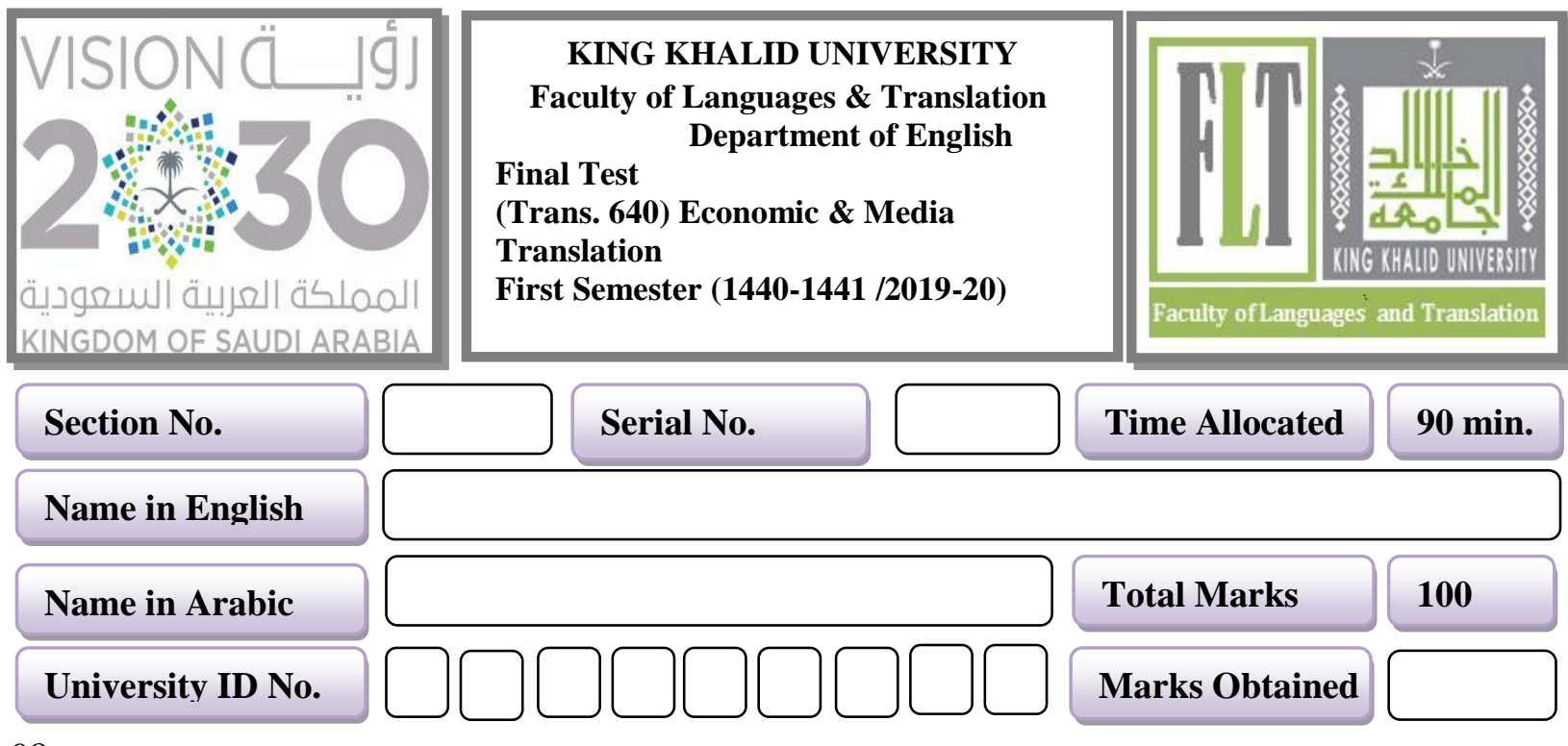

Time Allocated

$90 \mathrm{~min}$.

Total Marks

Marks Obtained
100 


\section{Q1- Translate the following journalistic text into Standard Arabic (60 marks):}

\section{Brazil can't stop deforestation without aid}

Deforestation is cutting or burning down of all the trees in an area. "Brazil can't stop deforestation in the Amazon without the help of the rich countries" the environment minister, Ricardo Salles, said at the United Nations' twoweek climate change conference.

Deforestation in the 12 months reached the highest annual rate in 11 years. Brazil's annual deforestation report showed a nearly 30 percent jump from the prior year in Amazon, which lost 3,769 square miles of forests. Therefore, Norway alone has donated 1.2 billion dollars to Brazil's Amazon Fund since its creation in 2008.

\section{Q4- Translate the following journalistic text into English (40 marks):}

آخر أخبار الإعصار الأخير في بحر العرب

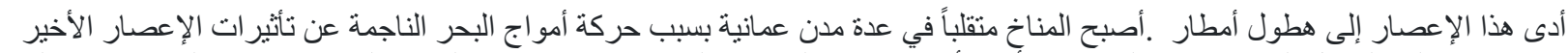

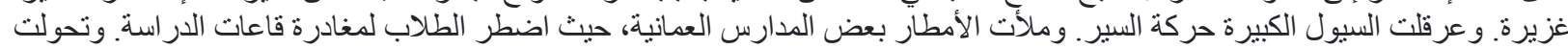

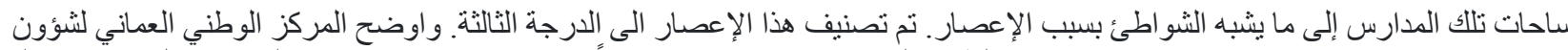
الطقس الثلاثاء ان الاعصار كبير جداً. وسوف تستمر حركته نحو الغرب خلال الإل 36 ساعة القادمة. 